\title{
Coping Strategies of Nigeria Higher Education Institutions during COVID-19 Lockdown
}

\author{
Bin Yan ${ }^{1}$ Aliyu Yusuf Moyi ${ }^{1,2^{*}}$ \\ 1. School of Civil Engineering, Central South University, Changsha, Hunan, 410075, China \\ 2. Department of Civil Engineering, Faculty of Engineering, Ahmadu Bello University Zaria, Kaduna State, 800242 , \\ Nigeria
}

\section{ARTICLE INFO}

Article history

Received: 6 August 2021

Revised: 14 August 2021

Accepted: 15 October 2021

Published Online: 30 October 2021

\section{Keywords:}

COVID-19

Coping strategies

Nigeria

Higher education institutions

\section{Introduction}

Pandemics are disease outbreaks that become widespread, across countries, as a result of the fast spread of the infection from human to human. The world has experienced series of pandemics in history, including the recent SARS, MERS, Spanish Flu, H7N9, Ebola, Hong Kong Flu, Zika and so on ${ }^{[2]},{ }^{[5-7]}$ with far reaching effects on economy ${ }^{[9]}$, health ${ }^{[8,1]}$, etc. and society's response as can be seen through transportation services and consumer (passenger) behaviour and related activities have become predictable ${ }^{[9]}$. Economic data from the 20th century pandemics such as the 1918-1919 Influenza pandemic is not readily available. However, the Federal Reserve Bank of St. Louis estimated that there were several losses

\section{ABSTRACT}

Beginning at the end of the year 2019, the novel coronavirus (COVID-19) has drowned the world into uncertainty and has threatened the continuity of traditional classroom learning that is the backbone and, in many cases, the main method of learning in most countries. This paper seeks to ascertain how Higher Institutions of learning in Nigeria have thrived during the lockdown period, based on the National policy document that spells out the guidelines for school reopening. Official documents such as newspaper reports university bulletins are used to corroborate in order to ascertain the implementation of the provisions of the policy guideline document as well as assess the efficacy of the measures on students' quality of learning. particularly in service-oriented ones, which rail transport falls into ${ }^{[23]}$. This is relevant in that it shows how the transport services enterprises can be affected by the modern-day pandemic ${ }^{[24]}$.

The Novel Corona Virus Infectious Disease first occurred around the end of the year 2019 in Wuhan, China, and outbroke in January 2020, a month later ${ }^{[11]}$. Since then, the whole world has experienced massive spread of the disease and affected countries have recorded several degrees of severity, with China, Spain, Italy and the US being the most hit, amongst other affected countries ${ }^{[12]}$.

Following the spread of the novel corona virus and its declaration as a pandemic by the World Health Organization in March $2020^{[4,15]}$, the world has seen unprecedented changes in the approach to doing things

*Corresponding Author:

Aliyu Yusuf Moyi,

School of Civil Engineering, Central South University, Changsha, Hunan, 410075, China; Department of Civil Engineering, Faculty of Engineering, Ahmadu Bello University Zaria, Kaduna State, 800242, Nigeria;

Email:1218190101@csu.edu.cn. 
and has had to welcome the reality of the "new normal" "[10]. Generally, the outbreak has severely impeded economic activities and process and transportation constraints have interrupted the supply chains of industries and enterprises, personnel quarantine has further slowed down economic activities throughout the world ${ }^{[38]}$. This has led to the inability of small and medium scale enterprises to resist the risks posed and, in most cases, with no capacity to maintain virtual functionality. To curtail the fast spread of the new corona virus infectious disease, the Chinese Government, adopted series of strict, non-pharmaceutical prevention and control measures, such as massive and strict city lock-downs and restricting people from entering and leaving their communities or using public transport infrastructure ${ }^{[13]}$. The world saw varying degrees and forms of replication of the Chinese idea toward curtailing the spread of the virus ${ }^{[14]}$. Through this bold, unpharmaceutical and unprecedented measures, considerable results were achieved and the spread reduced significantly ${ }^{[12]}$. However, these measures have inevitably restricted the movement of people and will in the future, cause for significant modification of operational processes in the railway transportation sector, so as to implement the WHO's social distancing regulations ${ }^{[16-20]}$.

As a direct consequence of social distancing measures occasioned by realities of COVID-19 pandemic, Nigeria shut down the entire education sector, e-services' consumers have experienced considerable change in consumption behavior ${ }^{[29]}$, such as drastic drop in passenger travel demand due to fear of infection and as according to government regulations, significant influence on choice of travel mode; where people would prefer to avoid public transportation due to large crowds and even those who can't afford private vehicles or uncrowded modes such as taxis would prefer to travel during off peak hours that are usually characterized by low passenger turn up ${ }^{[28]}$. There has also been a paradigm shift in trading mode from physical buying and selling to internet based virtual trading accompanied with home-delivery services ${ }^{[30]}$.

The onset of the disease has shut down industries, economies and has significantly changed the way people interact. But countries are already on the brink of economic collapse and are struggling to open up their economies, while implementing regulations to ensure that the people are safe. Unlocking the railway transportation sector is therefore a very crucial catalyst for rapid recovery of economic activities in these countries ${ }^{[21,22]}$.

Recently, many countries have eased down the lockdown, mostly in phased quotas, to allow for controlled movement of people, toward achieving a gradual reopening of the hitherto shut economy ${ }^{[17]}$.
In this work, the various coping strategies of higher education institutions in Nigeria during COVID-19 lockdown are explored. The second section of this work provides an overview of the various strategies used across the world in trying to manage the pandemic situation with a common goal of ensuring that learning and research in higher institutions of learning do not come to an abrupt end. In the third section, the coping strategies as provided in the policy document established by the related Nigerian authorities are discussed. In order to juxtapose the actual implementation of the developed policy framework, a verification survey was done to ascertain the various forms of strategies as adopted by these higher institutions. The results are presented and accordingly discussed in section four. Section five contains conclusions based on the objectives and findings of this study.

\section{Coping Strategies across the Globe}

In Nigeria and across the globe, COVID-19 pandemic had an impact, not only on people's health, but also on how they learn, work and lives ${ }^{[27]}$. This has prompted governments around the world to take a variety of steps to manage the outbreak, including stoppage of face-to-face teaching, closure of higher institutions there by forcing students to stay at home which might have resulted in a great deal of stress and uncertainty in their lives. More than 1.5 billion children and young people globally have been affected by school and university closures. This is what led to the development of some coping strategies during the pandemic. Some of the coping strategies adopted across the globe, especially around the education sector are as discussed as follows ${ }^{[3]}$.

\section{A) Increasing Readiness While Keeping Schools Open}

This involves implementing and encouraging preventive measures in schools as done by countries like Afghanistan, establishing protocols for dealing with illnesses and possible cases in schools as adopted by countries like Egypt, Russia and Belarus; utilizing the physical and human resources of the educational system to combat the spread of illnesses in communities as done in Liberia and Sierra Leone; and minimizing social and extracurricular activities to prevent physical contact as done by countries like Singapore and Russia ${ }^{[3]}$.

\section{B) Closure of Schools Across the Nation}

As the COVID-19 virus had a wider spread, an ample number of countries resolved to the closure of schools. Many policy makers were concerned that, while children and teens

DOI: http://dx.doi.org/10.26549/jetm.v5i2.7880 
appear to be less susceptible to the virus and have a lower case-fatality ratio, they may act as disease carriers, putting older family members at danger in areas around the world where multi-generational families are common ${ }^{[3]}$.

\section{C) Selective Closing of Schools}

As a temporary measure, some governments chose to segregate treatment regions by closing localized schools (for example India). These localized approaches expanded geographically to countries like Brazil, Canada and Australia ${ }^{[3]}$.

\section{D) Learning Loss Mitigation Through Remote Learning and Educational Resources}

Many countries turned to distant learning to compensate for missed school time, countries such as China, Italy, France, Germany, Saudi Arabia etc. had theirs to fully online. Other countries such as Lebanon send kids home with lessons as homework. In countries like Bulgaria, more than 800,000 accounts were created for all teachers and parents, publishers were mobilized to open the digital textbooks and learning materials for grades 1 to 10 , and two national TV channels will broadcast educational tv ${ }^{[3]}$.

\section{Coping Strategies of Higher Education in Nigeria}

Cases of COVID-19 in Nigeria were confirmed in February 2020, which led to the closure of schools and all learning facilities in March 2020 so as to safeguard the health and general well-being of the children, youths, teachers, and educational personnel. This brought about an unprecedented challenge to Nigeria's education sector, as an estimated 80million children, youth, and adult learners in the system are deprived access to schools and have very limited alternative learning opportunities. The closure of schools and learning facilities during the pandemic also resulted in further deterioration in facilities and capacities for the delivery of quality education. It is expected that the longer schools are closed, the more the learning loss, the greater the severity of inequality in the education sector and the greater the risk of exploitation for the most vulnerable children ${ }^{[25]}$.

The above factors were considered and a response had to be made to mitigate the negative impact the COVID-19 pandemic already had on the education sector. In order to do that, some guidelines and strategies for the safe reopening of schools and learning facilities were developed in a consultative and collaborative initiative of the Federal Ministry of Education with other bodies with the goal of supporting and enabling the implementation of the Nigeria Education Sector COVID-19 Response Strategy's objectives in a timely and safe manner. These guidelines were posed to also help learners, teachers, parents, guardians, communities, and the larger society to trust the process of reopening and be assured that learning will continue in a safe environment. In line with the Nigerian Government's drive and as explicitly defined in the final policy document, the coping strategies adopted in Nigeria were as follows ${ }^{[25]}$.

\section{A) Staying Home and Learning Safely before schools reopen}

This involves students and learners staying home and learning safely, and they should be involved in learning regardless of the type of distance learning employed in the location of the learner. Ensuring that these learners are safe involves sharing public health messages about COVID-19, including its symptoms, how it is transmitted and how to prevent transmission. It also involves protecting these learners from negative online effects since they will mostly be online. This form of learning also involves training or preparing teachers to teach in a way that safeguards the health, safety, and security of the learners and to enable the facilitation of learning using twenty-first century e-learning. In order to carry out this form of learning, the learners have to be provided with printed materials, online learning, radio, or TV program ${ }^{[25]}$.

\section{B) Reopening of Schools}

The reopening of schools was guided by considering the best interest of learners and overall public health, based on an assessment of the associated benefits and risks. Other countries like Ireland, Italy, and Luxembourg have proposed similar distances. The Governments of Italy and Ireland for instance, have made putting masks at learning institutions mandatory for persons greater than 6 and 13 years of age respectively ${ }^{[31-33]}$. The recommendations of the government to be followed as schools reopened are as follows.

\section{C) Safe distancing}

It was recommended in schools and other learning facilities, that learners should be supported to stay $2 \mathrm{~m}$ apart. This is as speculated by the Nigeria Centre for Disease Control (NCDC). This implies that classrooms, dining halls, staff rooms, and offices should have sufficient space to allow for two-meter separation between all individuals. However, there are exceptions where the two-meter rule cannot be applied reasonably, in which case, other risk mitigation strategies may be adopted ${ }^{[25]}$.

\section{D) Safe Distancing Alternative Learning Models}

As schools and learning facilities reopen, they started 
to implement safe distancing measures that minimize and isolate risk. So, some alternatives to safe distancing were developed to focus on flexibility in scheduling and content delivery for learners. The following were alternatives developed for flexibility in learning for learners ${ }^{[25]}$.

a. Outdoor learning: this involves learning outside the usual classrooms so that social distancing measures are better implemented, it is necessary for the protection and safety of learners and teachers. The use of outdoor spaces as alternatives to classrooms or other enclosed spaces or implementation of phased entry or both, as strategies to overcome space limitations that may stem from the need for social distancing can limit contamination and transmission ${ }^{[26]}$.

b. Staggered attendance: this is the case where learners do not all arrive and leave at the same time, but have large periods of overlap, or schools may reopen gradually (e.g., starting with a particular grade level before other grade levels). This is done to avoid overcrowding. Higher Education Institutions should establish and implement guidelines aimed at lessening the interactions between students in classrooms where they learn and study at night, as well as in the dormitories where they live. Johansen and Bonell et al suggested that strategies such as subgrouping, cohorting or bubbling classrooms be adopted such that in this case, lecturers go to teach students in their classrooms instead of the usual way that involves students moving from one lecture hall to the other ${ }^{[34,35]}$.

c. Alternate attendance: this involves the school alternative attendance for all learner per week, with some learners attending the school at certain days in the week in the absence of other learners.

d. Platooning: this is the case where classes usually held together may be divided into morning and afternoon shifts due to overcrowding.

e. Decreased interaction: this is the case where learners may remain in one location with teachers coming to them.

f. Flexible schedule: This is the situation when classes are designed in such a way that learners and staff do not need to move between different regions of the facility.

g. Creative delivery: In this situation, courses could be given in a more holistic manner to accommodate for diverse learning settings for in-person learning (indoor, outdoor) and various media for distance learning (printed materials, online, TV, and radio). Learners may have set aside time to learn in each of these settings in order to alleviate the strain on indoor facilities ${ }^{[25]}$.

\section{Methodology}

\section{Materials}

Official Documentation Released by Government
Institutions.

\section{Study Design}

This research study is a questionnaire-based survey where responses from a cross-section of students in the various Nigerian Higher Institutions such as monotechnic, polytechnics and universities are collected and analyzed. Thereafter, the responses on the nature of coping strategies as standardized by the "GUIDELINES FOR SCHOOLS AND LEARNING FACILITIES REOPENING AFTER COVID-19 PANDEMIC CLOSURES" policy document produced by the Nigerian Federal Ministry of Education are then corroborated against official news channels like university bulletin releases and major newspapers in order to ascertain the veracity of the responses and the news headlines.

\section{Study Setting}

Nigeria's education system encompasses three major sectors: basic education consisting of 6 years primary education and 3 years Junior Secondary School education (nine years), post-basic/senior secondary school education (3years), and tertiary education (4 to 6 years, depending on the program of study).

The structure of Nigeria's tertiary education closely resembles that of the United States of America. The Nigerian Higher Education structure consists of Universities, Polytechnics, Colleges of Education and Monotechnics. In order to assess the coping strategies of Nigerian Higher Education institutions in general, the survey was expanded to include all of these component structures of the higher education system. Since the important aim of this study is to ascertain the different coping strategies employed by the Nigerian Higher Institutions of learning, the responses of the survey are corroborated with official print news sources within the scope of the "GUIDELINES FOR SCHOOLS AND LEARNING FACILITIES REOPENING AFTER COVID-19 PANDEMIC CLOSURES" policy document produced by the Federal Ministry of Education in line with the guidelines of the World Health Organization (WHO) and the Nigeria Centre for Disease Control (NCDC) which are the statutory organizations for the management and regulation policies in the world and Nigeria respectively.

\section{Study sample}

A total of 122 respondents filled the questionnaire. According to the Raosoft online sample size calculator, a solely survey-based study requires at least 450 respondents. But since the aim of this study is to ascertain those strategies that were implemented in higher institutions of learning in Nigeria, the results of the 
survey are validated with official information channels like university bulletin releases and major newspapers as has already been pointed out in the study design section above.

\section{Data Collection Tool}

A google form online questionnaire was developed for this study and based on print and electronic literature, possible questions were developed to fit the research objectives of the study. After review, the final draft was then entered into a Google form whose link was shared across the target sample space in order to collect responses. Cronbach's coefficient alpha analysis was run to establish internal consistency and overall reliability of the instrument and responses.

\section{Study procedure}

The link to the prepared Google form was sent to the target students of the various higher institutions of learning after obtaining the student consent. This link was shared widely using social media and word of mouth. To ensure veracity of responses, Google form by default, does not allow multiple completions.

\section{Data Management and Analysis}

After responses were collected, the spreadsheet file was downloaded and reviewed for completeness, even though it was made a requirement for completing the questionnaire, for respondents to respond to all questions. The data were cleaned and then exported to the Statistical Product and Service Solutions Software (SPSS) and Microsoft Excel where the data was further analyzed. Students' responses were summarized using descriptive statistics like frequency and percentage tables and Cronbach alpha's analysis was employed to evaluate the internal consistency of the responses.

\section{Results}

\section{Socio-demographic characteristics of the higher education students}

The majority of the respondents are university students $(117,95.9 \%)$, followed by students of colleges of education $(3,2.5 \%)$ and polytechnic students $(2$, $1.6 \%$ ). Out of the entire 122 students who responded to the questionnaire, $91(74.6 \%)$ are undergraduates while the rest $(31,25.4 \%)$ are postgraduate students involving $94(77 \%)$ male students and 28 (23\%) female students who are between 18 years and 44 years. In Table 1, the demographics of the respondent students including age, gender, level of education, place of residence during the lockdown and place of residence of the higher education institution concerned are shown in Table 1 below.

Table 1. Socio-demographic characteristics of the Higher Education Students

\begin{tabular}{lll}
\hline Characteristics & Frequency & Percentage (\%) \\
\hline Age (years) & 52 & 42.6 \\
$18-24$ & 62 & 50.8 \\
$25-34$ & 8 & 6.6 \\
$35-44$ & 0 & 0.0 \\
Greater than 44 & $\mathbf{1 2 2}$ & $\mathbf{1 0 0 . 0}$ \\
\hline Total & & \\
Gender & 94 & 77.0 \\
Male & 28 & 23.0 \\
Female & $\mathbf{1 2 2}$ & $\mathbf{1 0 0 . 0}$ \\
Total & & \\
\hline Level of Higher Education & 91 & 74.6 \\
Undergraduate & 31 & 25.4 \\
Postgraduate & $\mathbf{1 2 2}$ & $\mathbf{1 0 0 . 0}$ \\
Total & & \\
\hline
\end{tabular}

Respondents' Current Higher Education of Learning

$\begin{array}{lll}\text { University } & 117 & 95.9 \\ \text { Polytechnic } & 2 & 1.6 \\ \text { College } & 3 & 2.5 \\ \text { Total } & \mathbf{1 2 2} & \mathbf{1 0 0 . 0}\end{array}$

State of Residence of the Institutions

\begin{tabular}{lll} 
Kaduna & 73 & 59.84 \\
Kano & 17 & 13.93 \\
Kebbi & 2 & 1.64 \\
Lagos & 9 & 7.38 \\
Plateau & 2 & 1.639344 \\
Enugu & 2 & 1.639344 \\
Niger & 3 & 2.459016 \\
FCT & 2 & 1.639344 \\
\hline
\end{tabular}




\begin{tabular}{lll}
\hline Characteristics & Frequency & Percentage (\%) \\
\hline Kwara & 3 & 2.459016 \\
Nasarawa & 2 & 1.639344 \\
Sokoto & 3 & 2.459016 \\
Borno & 1 & 0.819672 \\
Delta & 1 & 0.819672 \\
Gombe & 1 & 0.819672 \\
Jigawa & 1 & 0.819672 \\
Total & $\mathbf{1 2 2}$ & $\mathbf{1 0 0}$ \\
\hline
\end{tabular}

State of Residence during COVID Lockdown

\begin{tabular}{|c|c|c|}
\hline Kaduna & 37 & 30.32787 \\
\hline Kano & 19 & 15.57377 \\
\hline Kebbi & 11 & 9.016393 \\
\hline Lagos & 10 & 8.196721 \\
\hline Katsina & 4 & 3.278689 \\
\hline Kebbi & 6 & 4.918033 \\
\hline Kogi & 2 & 1.639344 \\
\hline Kwara & 2 & 1.639344 \\
\hline Nasarawa & 8 & 6.557377 \\
\hline Niger & 1 & 0.819672 \\
\hline Ogun & 2 & 1.639344 \\
\hline Оуо & 2 & 1.639344 \\
\hline Plateau & 3 & 2.459016 \\
\hline Rivers & 2 & 1.639344 \\
\hline Sokoto & 1 & 0.819672 \\
\hline Zamfara & 1 & 0.819672 \\
\hline Adamawa & 3 & 2.459016 \\
\hline Bauchi & 4 & 3.278689 \\
\hline Borno & 2 & 1.639344 \\
\hline Edo & 1 & 0.819672 \\
\hline Jigawa & 1 & 0.819672 \\
\hline Total & 122 & 100 \\
\hline
\end{tabular}

In order to cope with the lockdown, Nigerian Higher Education Institutions adopted several coping strategies that best suit their situation and within the provisions of the government's guidelines. Table 2 below shows the coping strategies according to how the respondents have opined. Staggered attendance $(55,41.4 \%)$ had the highest implementation in universities (because they constitute the majority the respondent's higher education institutions) followed by creative delivery $(23,17.3 \%)$, decreased interaction $(14,10.5 \%)$, then outdoor learning and flexible schedule with 13 each or $9.8 \%$ of the total 133 (some respondents chose more options) responses.

Table 2. Coping strategies employed by universities

\begin{tabular}{lll}
\hline Coping Strategies employed by universities & & \\
\hline Creative delivery & 23 & 17.3 \\
Staggered attendance & 55 & 41.4 \\
Decreased interaction & 14 & 10.5 \\
Outdoor learning & 13 & 9.8 \\
Flexible schedule & 13 & 9.8 \\
Platooning & 15 & 11.3 \\
Total & $\mathbf{1 3 3}$ & $\mathbf{1 0 0 . 0}$ \\
\hline
\end{tabular}

Table 3 shows the coping strategies adopted by some of the understudied Higher institutions of learning as corroborated by official news sources. As is seen in the table, Ahmadu Bello University, Bayero University Kano and University of Lagos all adopted the decreased interaction and creative delivery strategies while Ahmadu Bello University adopted staggered attendance in addition to the strategies adopted by the other two universities.

Table 3. Coping Strategies employed by universities (official information sources)

\begin{tabular}{ccc}
\hline University & Coping strategy & Source \\
\hline $\begin{array}{c}\text { Ahmadu Bello } \\
\text { University, } \\
\text { Zaria }\end{array}$ & $\begin{array}{c}\text { Staggered attendance, } \\
\text { Decreased interaction, } \\
\text { creative delivery }\end{array}$ & University website [39] \\
Bayero & Decreased interaction, & \\
Cniversity, \\
Kano & Creative delivery & $\begin{array}{c}\text { Premium Times online } \\
\text { newspaper [41] }\end{array}$ \\
& & \\
University of & Decreased interaction, & University website [42] \\
Lagos & creative delivery & \\
\hline
\end{tabular}

In ${ }^{[36]}$, Sintema posits that due to incidents of reduced teacher-student contact hour and lack of consultation with teachers when students face challenges in grasping lecture contents, academic performance will drop for class period held during the lockdown.

Table 4 below shows an assessment of the impact of COVID-19 lockdown on how the students of higher 
education thrived. From the foregoing, majority of students $(60,49.2 \%)$ reported that their academic performances compared with the pre-covid times was virtually the same, followed by $34.4 \%$ who reported that their performances became worse - a confirmation of Sintema's position. Here, it is important to note that the majority of these respondents are students of Ahmadu Bello University who had the phased resumption type of strategy for mitigating the effects of COVID-19 on their learning activities.

Majority of the respondents $(53,43.4 \%)$ reported that they had difficulty concentrating in online learning platforms as well as the new learning approaches they were subjected to, during the lockdown, and only 16.4 $\%$ or 20 respondents reported the that they faced no difficulty, and this is anchored on the mostly physical contact students and learners had during this period. This is in line with Bao's ${ }^{[37]}$ conclusion in her article as to establish the occurrence of low concentration levels in students during the lockdown and thereby, recommended the adjustment of the teaching speed so as to ensure effective learning.

39 students (32\%) reported moderate feeling of lethargy, $20.5 \%$ reported anxiety, $27 \%$ reported no effect in sleep pattern and so on as the trend repeats itself throughout the assessment. No effect in sleep pattern may be attributed to the very friendly measures by the Ahmadu Bello University management where the major change occurred only in the number of students who could resume, keeping learning activities nearly the same as was obtainable pre-COVID.

Table 4. Impact of COVID-19 Lockdown on the Learning process of Higher Education Students

\begin{tabular}{lcc}
\hline Variables & Frequency & Percentage (\%) \\
\hline Academic performance during the COVID-19 & period in school \\
Better & 20 & 16.4 \\
Worse & 42 & 34.4 \\
Remained the same & 60 & 49.2 \\
Total & $\mathbf{1 2 2}$ & $\mathbf{1 0 0 . 0}$ \\
\hline Difficulty concentrating & \\
No Difficulty & 20 & 16.4 \\
Little Difficulty & 22 & 18.0 \\
Moderate Difficulty & 53 & 43.4 \\
Much Difficulty & 19 & 15.6 \\
\hline
\end{tabular}

\begin{tabular}{lll}
\hline Variables & Frequency & Percentage (\%) \\
\hline Extreme Difficulty & 8 & 6.6 \\
Total & $\mathbf{1 2 2}$ & $\mathbf{1 0 0}$ \\
\hline
\end{tabular}

Lethargy or Lack of Motivation

\begin{tabular}{lcc} 
No Lethargy & 13 & 10.7 \\
Little Lethargy & 17 & 13.9 \\
Moderate Lethargy & 39 & 32.0 \\
Much Lethargy & 33 & 27.0 \\
Extreme lethargy & 20 & 16.4 \\
Total & $\mathbf{1 2 2}$ & $\mathbf{1 0 0}$ \\
\hline
\end{tabular}

Depression or Anxiety

\begin{tabular}{lcc} 
No Anxiety & 21 & 17.2 \\
Little Anxiety & 25 & 20.5 \\
Moderate Anxiety & 41 & 33.6 \\
Much Anxiety & 24 & 19.7 \\
Extreme Anxiety & 11 & 9.0 \\
Total & $\mathbf{1 2 2}$ & $\mathbf{1 0 0}$ \\
\hline
\end{tabular}

Sleep pattern affected

\begin{tabular}{lcc} 
No Effect & 33 & 27.0 \\
Little Effect & 16 & 13.1 \\
Moderate Effect & 41 & 33.6 \\
Much Effect & 20 & 16.4 \\
Extreme Effect & 12 & 9.8 \\
Total & $\mathbf{1 2 2}$ & $\mathbf{1 0 0}$ \\
\hline Loneliness & & \\
No Loneliness & 30 & 24.6 \\
Little Loneliness & 17 & 13.9 \\
Moderate Loneliness & 31 & 25.4 \\
Much Loneliness & 22 & 18.0 \\
Extreme Loneliness & 22 & $\mathbf{1 0 0}$ \\
Total & $\mathbf{1 2 2}$ & 18.0 \\
\hline
\end{tabular}




\begin{tabular}{|c|c|c|}
\hline Variables & Frequency & Percentage $(\%)$ \\
\hline \multicolumn{3}{|c|}{ Physical Health in the COVID-19 Period } \\
\hline $\mathrm{Bad}$ & 4 & 3.3 \\
\hline Fair & 11 & 9.0 \\
\hline Good & 41 & 33.6 \\
\hline Very Good & 40 & 32.8 \\
\hline Excellent & 26 & 21.3 \\
\hline Total & 122 & 100 \\
\hline \multicolumn{3}{|c|}{ Adjustment to Online Learning } \\
\hline No Adjustment & 33 & 27.0 \\
\hline Little Adjustment & 17 & 13.9 \\
\hline $\begin{array}{l}\text { Moderate } \\
\text { Adjustment }\end{array}$ & 34 & 27.9 \\
\hline Much Adjustment & 21 & 17.2 \\
\hline Extreme Adjustment & 17 & 13.9 \\
\hline Total & 122 & 100 \\
\hline \multicolumn{3}{|c|}{ Struggle to Establish New Routine } \\
\hline Extreme Struggles & 21 & 17.2 \\
\hline Much Struggles & 24 & 19.7 \\
\hline Moderate Anxiety & 36 & 29.5 \\
\hline Little Struggles & 22 & 18.0 \\
\hline No Struggles & 19 & 15.6 \\
\hline Total & 122 & 100 \\
\hline \multicolumn{3}{|c|}{ Logistical Problems with Online Learning } \\
\hline Extreme Problems & 21 & 17.2 \\
\hline Much Problems & 20 & 16.4 \\
\hline Moderate Problems & 45 & 36.9 \\
\hline Little Problems & 11 & 9.0 \\
\hline No Problems & 25 & 20.5 \\
\hline Total & 122 & 100 \\
\hline \multicolumn{3}{|c|}{ Problems with Instructors } \\
\hline Extreme problems & 8 & 6.6 \\
\hline Much problems & 24 & 19.7 \\
\hline Moderate problems & 44 & 36.1 \\
\hline Little Problems & 27 & 22.1 \\
\hline No problems & 19 & 15.6 \\
\hline Total & 122 & 100 \\
\hline
\end{tabular}

Table 5 shows a concise summary of COVID-19 situation report in Nigeria. During the COVID lockdown, the situation of the different states was classified according to the tabulated risk factors and other factors like availability of test and quarantine centers. States with high, medium and low number of confirmed cases were classified as high, medium and low risk states with the consideration of availability of laboratory testing facilities. Lagos state had the highest number of confirmed cases (61122, 36.1\%), followed by the Federal Capital Territory
Abuja (19927, 11.75\%). These records were due largely to the actual spread, but more importantly, to the availability of testing centers.

Table 5. Summary of Latest NCDC report on COVID-19 situation in Nigeria as at 18/07/2021

\begin{tabular}{|c|c|c|c|c|}
\hline $\begin{array}{c}\text { States } \\
\text { Affected }\end{array}$ & $\begin{array}{c}\text { No. of } \\
\text { Cases (Lab } \\
\text { Confirmed) }\end{array}$ & $\begin{array}{c}\text { No. of } \\
\text { Cases (on } \\
\text { admission) }\end{array}$ & $\begin{array}{c}\text { No. } \\
\text { Discharged }\end{array}$ & $\begin{array}{l}\text { No. of } \\
\text { Deaths }\end{array}$ \\
\hline Lagos & 61,122 & 2,151 & 58,515 & 456 \\
\hline FCT & 19,927 & 40 & 19,719 & 168 \\
\hline Kaduna & 9,127 & 4 & 9,058 & 65 \\
\hline Plateau & 9,068 & 3 & 9,008 & 57 \\
\hline Rivers & 7,415 & 71 & 7,243 & 101 \\
\hline Оуо & 6,910 & 43 & 6,739 & 128 \\
\hline Edo & 4,914 & 4 & 4,725 & 185 \\
\hline Ogun & 4,723 & 25 & 4,645 & 53 \\
\hline Kano & 4,006 & 3 & 3,893 & 110 \\
\hline Ondo & 3,497 & 19 & 3,413 & 65 \\
\hline Kwara & 3,160 & 37 & 3,068 & 55 \\
\hline Delta & 2,654 & 26 & 2,556 & 72 \\
\hline Osun & 2,578 & 6 & 2,520 & 52 \\
\hline Enugu & 2,482 & 18 & 2,435 & 29 \\
\hline Nasarawa & 2,385 & 1 & 2,345 & 39 \\
\hline Gombe & 2,117 & 12 & 2,061 & 44 \\
\hline Katsina & 2,112 & 23 & 2,055 & 34 \\
\hline Ebonyi & 2,039 & 5 & 2,002 & 32 \\
\hline Akwa Ibom & 1,989 & 54 & 1,917 & 18 \\
\hline Anambra & 1,909 & 64 & 1,826 & 19 \\
\hline Abia & 1,693 & -2 & 1,673 & 22 \\
\hline Imo & 1,661 & 0 & 1,624 & 37 \\
\hline Bauchi & 1,549 & 0 & 1,532 & 17 \\
\hline Benue & 1,366 & 15 & 1,327 & 24 \\
\hline Borno & 1,344 & 1 & 1,305 & 38 \\
\hline Adamawa & 1,134 & 4 & 1,098 & 32 \\
\hline Taraba & 1,001 & 0 & 977 & 24 \\
\hline Niger & 935 & 5 & 913 & 17 \\
\hline Bayelsa & 907 & 2 & 879 & 26 \\
\hline Ekiti & 897 & 19 & 867 & 11 \\
\hline Sokoto & 775 & 0 & 747 & 28 \\
\hline Jigawa & 536 & 8 & 512 & 16 \\
\hline Yobe & 499 & 0 & 490 & 9 \\
\hline Kebbi & 450 & 42 & 392 & 16 \\
\hline Cross River & 402 & 0 & 384 & 18 \\
\hline Zamfara & 244 & 3 & 233 & 8 \\
\hline Kogi & 5 & 0 & 3 & 2 \\
\hline Total & 169,532 & 2,706 & 164,699 & 2127 \\
\hline
\end{tabular}




\section{Conclusions}

This research elaborates on the coping strategies of Nigeria Higher education institutions that were implemented to deal with the novel problems created by the emergence of the pandemic. Given the findings, we can conclude that the higher education institutions largely implemented the provision of the Government prepared national policy and guidance document on management of COVID-19 during lockdown and school reopening. Moreover, the following conclusions can be derived:

(1) Due to the current disadvantageous realities with regards to internet connectivity, access and spread, a fully online switch from traditional classroom learning style is not realistic for majority of the students in Nigeria Higher Education institutions of learning.

(2) In assessment of the impact of the COVID19 lockdown on the learning process of the subject students, there was mild effect on academic performance, students' motivation to learning, sleeping pattern, problems with instructors and the overall measure of how students thrived in learning, in trying to cope with the new changes. And this is largely due to the phased resumption model of the policy document proposed by the Government, amongst other auxiliary COVID measures like social distancing, face mask wearing, hand washing practices, and so on.

(3) In the near future and as a matter of urgency, it is recommended to the Nigerian authorities to prioritize the provision of online learning facilities for tertiary education students in preparation for future occurrences of similar situations that may again put students in a dilemma. No country can survive without educating their young ones and a threat to education and learning in any guise, must be confronted firmly.

\section{References}

[1] Yin X, Wang J, Feng J, Chen Z, Jiang N, Wu J et al. The Impact of the Corona Virus Disease 2019 Outbreak on Chinese Residents' Mental Health. [Preprint]. Bull World Health Organ. E-pub: 8 April 2020.

DOI: http://dx.doi.org/10.2471/BLT.20.258475.

[2] Zhu N, Zhang D, Wang W, Li X, Yang B, Song J, et al. A Novel Coronavirus from Patients with Pneumonia in China, 2019. N Engl J Med. 2020; 382(8): 727-733.

DOI: 10.1056/NEJMoa2001017 PMID: 31978945.

[3] "Managing the impact of COVID-19 on education systems around the world: How countries are preparing, coping, and planning for recovery." https://blogs. worldbank.org/education/managing-impact-covid- 19-education-systems-around-world-how-countriesare-preparing (accessed Jul. 14, 2021).

[4] Jamie Gumbrecht and Jacqueline Howard, C., 2020. WHO Declares Novel Coronavirus Outbreak A Pandemic. [online] CNN. Available at: $<$ https://edition. cnn.com/2020/03/11/health/coronavirus-pandemic-world-health-organization/index.html $>$ [Accessed 14 June 2020].

[5] W. Qiu; S. Rutherford; A. Mao; C. Chu. The Pandemic and its Impacts. Vol 9-10 (2016-2017) ISSN 2161-6590 (online). DOI 10.5195/hcs.2017.221 http://hcs.pitt.edu.

[6] WHO. (2011b). Comparative Analysis of National Pandemic Influenza Preparedness Plans.

[7] Rewar, S., Mirdha, D., \& Rewar, P. (2015). Treatment and Prevention of Pandemic H1N1 Influenza. Annals of Global Health, 81(5), 645-653.

DOI: http://dx.doi.org/10.1016/j.aogh.2015.08.014.

[8] Ribeiro, G. S., \& Kitron, U. (2016). Zika virus pandemic: a human and public health crisis. Revista da Sociedade Brasileira de Medicina Tropical, 49(1), 1-3.

[9] Estimating and projecting air passenger tra $\square \mathrm{c}$ during the COVID-19 coronavirus outbreak and its socio-economic impact Stefano Maria Iacus $\square$, Fabrizio Natale, Carlos Santamaria, Spyridon Spyratos, Michele Vespe. Estimating and projecting air passenger tra $\square \mathrm{c}$ during the COVID-19 coronavirus outbreak and its socio-economic impact. Safety Science 1229 (2020) 104791.pg 13.

[10] Alessio, T., Celestino, S. M. and Armando C. Z (2020). COVID-19 IMPACT IN TRANSPORT, AN ESSAY FROM THE RAILWAYS' SYSTEMS RESEARCH PERSPECTIVE. European Rail Research Network of Excellence.

[11] Wei L., Xiao-Guang Y., and Paul B. T., "Response to the COVID-19 Epidemic: The Chinese Experience and Implications for Other Countries", 2020. International Journal of Environmental Research and Public Health. Pg 6.

[12] Worldometer, "COVID-19 coronavirus pandemic", accessible online at: https://www.worldometers.info/ coronavirus/. Last updated June 15, 2020.

[13] In Coronavirus Fight, China Gives Citizens a Color Code, With Red Flags. Available online: https://www. nytimes.com/2020/03/01/business/china-coronavirus-surveillance.html (accessed on 1 March 2020).

[14] Du, Z.; Wang, L.; Cauchemez, S.; Xu, X.; Wang, X.; Cowling, B.J.; Meyers, L.A. Risk for Transportation of 2019Novel Coronavirus Disease from Wuhan to Other Cities in China. Emerg. Infect. Dis. 2020, 26. 
[CrossRef] [PubMed].

[15] Angus McNeice (2020). WHO declares COVID-19 pandemic. Updated: 2020-03-12 00:42. http:// www.chinadaily.com.cn/a/202003/12/WS5e6914dda31012821727e4a5.html.

[16] Drake, T. L., Chalabi, Z., \& Coker, R. (2012). Cost-effectiveness analysis of pandemic influenza preparedness: what's missing? Bull World Health Organ, 90(12), 940-941.

DOI: 10.2471/BLT.12.109025.

[17] Rail Transport to resume when domestic flight begins. Available online: https://thenationonlineng.net/ rail-transport-to-resume-when-domestic-flight-begins/ (updated on June 16, 2020).

[18] Preventive measures of COVID-19 by Sri Lanka Railways. A powerpoint presentation. Accessed online on June, 2020. accessible at http://www. railway.gov.lk/web/images/pdf/2020.05.01/system $\% 20$ for $\% 20$ rail $\% 20$ transportation $\% 20$ during $\% 20$ covid\%2019\%20final.pdf.

[19] Indian Railways (2020). Prevention of COVID-19 Infection. http://www.indianrailways.gov. in/railwayboard/view_section.jsp?lang=0\& $\mathrm{id}=0,1,304,366,519,2308$.

[20] Anisha Dutta (2020). Rush for tickets, guidelines issued for passenger trains. Hindustan Times, New Delhi. Published May 12, 2020. Online access: https://m.hindustantimes.com/india-news/rush-fortickets-guidelines-issued-for-passenger-trains/story-g86A9r9I7xROtKyJzoOYaM.html.

[21] HEAD TROPICS (2020). Coronavirus Has Been a Boon for China's Railways. Published 5/13/2020. https://headtopics.com/us/coronavirus-has-been-aboon-for-china-s-railways-13002057.

[22] Wade Shepard (2020). China-Europe Rail Is Set To Boom As COVID-19 Chokes Air, Sea And Road Transport. March 31,2020. https://www.forbes.com/ sites/wadeshepard/2020/03/31/china-europe-rail-isset-to-boom-as-covid-19-chokes-air-sea-and-roadtransport/\#321c85637dbb.

[23] Federal Reserve Bank of St. Louis. "Economic Effects of the 1918 Influenza Pandemic." Accessed March 20, 2020.

[24] Daniel Kurt (2020). The Special Economic Impact of Pandemics. Accessed June 6, 2020. https://www. investopedia.com/special-economic-impact-of-pandemics-4800597.

[25] Federal Ministry of Education, "Guidelines for Schools and Learning Facilities Reopening After Covid-19 Pandemic Closures," Fed. Minist. Educ., pp. 1-52, 2020, [Online]. Available: https://covid19.
ncdc.gov.ng/media/files/COVID_19_GUIDELINES_ FOR_SAFE_REOPENING.pd.

[26] N. Ziauddeen, K. Woods-Townsend, S. Saxena, R. Gilbert, and N. A. Alwan, "Schools and COVID-19: Reopening Pandora's box?," Public Health in Practice, vol. 1, p. 100039, 2020.

DOI: https://doi.org/10.1016/j.puhip.2020.100039.

[27] WHO (2020). Coronavirus disease (COVID-19) Situation Report - 151. World Health Organization. Published on 19th June, 2020. Accessed: 19th June, 2020.

[28] Jonas D.V. (2020). The Effect of COVID-19 and Subsequent Social distancing on travel behavior. Transportation Research Interdisciplinary Perspectives. 5(2020) 100121. pg 3. http://dx.doi.org/10.1016/ j.trip.2020.100121.

[29] Wilder-Smith, A., Freedman, D.O., 2020. Isolation, quarantine, social distancing and community containment: pivotal role for old-style public health measures in the novel coronavirus $(2019-\mathrm{nCoV})$ outbreak. J. Travel Med. https://doi.org/10.1093/jtm/ taaa020.

[30] Shi, K., DeVos, J., Yang, Y., Witlox, F.,2019. Doese shopping replace shopping trips? Empirical evidence from Chengdu, China. Transp. Res. A 122, 21-33.

[31] Ministère de L'Éducation Nationale, de L'enfance et de la Jeunesse (Luxembourg). Dispositif pour la Rentrée Scolaire 2020-2021 dans le Contexte de la Crise Sanitaire COVID-19. Available online: https:// gouvernement.lu/fr/actualites/toutes_actualites/articles/2020/09-septembre/04-meisch-briefing.html (accessed on 26 November 2020).

[32] Office of the Deputy Prime Minister Ministry for Health (Malta). Advice and Guidelines to the Educational Sector for the Re-Opening of Primary and Secondary Schools in Malta. August 2020. Available online: https://deputyprimeminister.gov. $\mathrm{mt} / \mathrm{en} /$ health-promotion/covid-19/Documents/mitigation-conditionsand-guidances/Advice-and-guidelines-for-educational-sector_02Sep20.pdf (accessed on 1 October 2020).

[33] The Department of Education and Skills (Ireland). COVID-19 Response Plan for the Safe and Sustainable Reopening of Primary and Special Schools V2. August 2020. Available online: https://assets.gov. ie/82063/ f53cc783-ed0a-4e55-bac0-18133323e90d. pdf (accessed on 1 October 2020).

[34] C. Bonell et al., "An evidence-based theory of change for reducing SARS-CoV-2 transmission in reopened schools," Health \& Place, vol. 64, p. 102398, 2020. 
DOI: https://doi.org/10.1016/j.healthplace.2020.102398.

[35] T. Johansen et al., "Infection prevention guidelines and considerations for pediatric risk groups when reopening primary schools during COVID-19 pandemic, Norway, April 2020," Euro surveillance, vol. 25, Jun. 2020.

DOI: 10.2807/1560-7917.ES.2020.25.22.2000921.

[36] Sintema, E. J. (2020 April 7). Effect of COVID-19 on the performance of grade 12 students: Implications for STEM education. EURASIA Journal of Mathematics, Science and Technology Education, 16(7). https://doi.org/10.29333/ejmste/7893.

[37] Bao, W. COVID-19 and online teaching in higher education: A case study of Peking University. Hum
Behav \& Emerg Tech. 2020; 2: 113- 115. https://doi. org/10.1002/hbe2.191.

[38] McKibbin, W.J.; Fernando, R. The Global Macroeconomic Impacts of COVID-19: Seven Scenarios. SSRN. Electron. J. 2020.

[39] https://www.abu.edu.ng.

[40] https://www.vanguardngr.com/2021/01/schoolresumption-buk-set-up-covid-19-protocol-enforcement-marshals/.

[41] https://www.premiumtimesng.com/regional/ nwest/436965-covid-19-buk-introduces-online-sessions-for-general-courses.html.

[42] https://unilag.edu.ng/. 